\title{
Supervision of school principal clinicals in junior high school
}

\author{
Darmawati \\ SMA Negeri 2 Ogan Komering Ulu
}

\begin{tabular}{|c|c|}
\hline A & ABSTRACT \\
\hline Article history: & \multirow{4}{*}{$\begin{array}{l}\text { This study aims to determine the implementation of head clinical supervision } \\
\text { school starts from planning, implementation and follow-up as well the success } \\
\text { of the principal's academic supervision in improving competence professional } \\
\text { teacher. This research uses a qualitative approach descriptive. Data collection } \\
\text { techniques through observation and interviews. The results of the study based } \\
\text { on the data obtained indicate that the implementation process of clinical } \\
\text { supervision at SMPN } 4 \text { Banyuasin III has been going well and has received } \\
\text { support from the principal and staff as well as the teachers concerned. In this } \\
\text { clinical supervision, each stage carried out is able to provide meaning that can } \\
\text { increase the ability of teachers to manage learning. The stages referred to are } \\
\text { between the initial meeting, the learning observation stage to the post-feedback } \\
\text { stage. Clinical supervision is a solution that is quite effective in improving } \\
\text { teacher skills. This, it can be seen from the final results of the study that the } \\
\text { teacher is able to master learning with various methods in accordance with the } \\
\text { learning objectives. }\end{array}$} \\
\hline $\begin{array}{l}\text { Received Jul } 12^{\text {th }}, 2021 \\
\text { Revised Aug } 17^{\text {th }}, 2021 \\
\text { Accepted Aug } 30^{\text {th }}, 2021\end{array}$ & \\
\hline Keyword: & \\
\hline $\begin{array}{l}\text { Implementation of Supervision } \\
\text { Clinical Supervision } \\
\text { Clinical Supervision of Principals }\end{array}$ & \\
\hline
\end{tabular}

(C) 2021 The Authors. Published by IICET.

This is an open access article under the CC BY-NC-SA license

(https://creativecommons.org/licenses/by-nc-sa/4.0

\section{Corresponding Author:}

Darmawati

SMA Negeri 2 Ogan Komering Ulu

Email: darmaakmal@gmail.com

\section{Introduction}

The principal is a teacher who is given additional assignments by the authorities to lead a school. When the school has a state status, the head of the school assigns the regent, mayor and governor depending on the level of education. However, it is different for schools with private status, so the one who assigns them is the head of the foundation. The presence of the principal is very necessary in the education unit because the principal is responsible for the implementation of education and learning at school. Of course the principal must really understand the main duties and function.

The statement above is in line with the following opinion that the implementation of education needs to be done in an integrated manner. The implementation of education is integrated between the principal and the teacher. The integration of the two has a very big role in schools [1].

In addition, there is an opinion that the principal performs his duties and functions in relation to the teaching process. The school principal has full duties, responsibilities, authority and rights in carrying out the task of supervising subjects [2]. From the statements above, one of the duties of the principal is to supervise the learning process.

Now there are new developments in the learning and education system. There is a strong tendency that in order to improve quality and professionalism, teachers need to be nurtured and restructured. This should 
involve assistance and guidance from a supervisor. The principal has an obligation to assist and provide support to teachers so that their duties as educators and teachers can be carried out properly.

The principal as a supervisor is responsible for his efforts to improve the ability of teachers when managing learning activities at school. In addition, it also has an important role in the process of school development and progress. In terms of supervision, the principal must carry out it properly and correctly in accordance with the principles of supervision and use the right techniques and approaches.

Currently, there is a model for teaching supervision activities, namely clinical supervision. Because teaching is not easy, it is not just a process of conveying information and teaching is a complex act that is full of elements of technology, science, art, and choice of values, it is necessary to carry out supervision to measure the level of success of teachers in the learning process.

Clinical supervision is a model of supervision whose implementation is more emphasized on the causes or weak points that occur during the learning process. Furthermore, immediately, repair services are provided for these weaknesses or shortcomings. On the other hand, there is such a thing as academic supervision which aims to improve the quality of learning. The scope is narrow, only focuses on the academic aspects, especially what happens in the classroom when the teacher is learning and direction to students. However, academic activities in the learning process also require attention so that clinical supervision is carried out so that various aspects of the uniqueness and complexity of the learning process are carried out properly.

Richard Waler in Ngalim Purwanto defines clinical supervision as supervision that is focused on improving teaching by going through a systematic cycle of stages, planning, observing, and intensively analyzing intellectual performance of actual teaching with the aim of making optimal modifications [3].

Clinical supervision aims to assist teachers in reducing the mismatch between real teaching behavior and professional behavior. In practice, clinical supervision is characterized by, among others: supervisor guidance to teachers in the form of assistance, not orders or instructions; the types of skills being supervised are proposed by the teacher to be supervised and mutually agreed between teachers and supervisors; clinical supervision targets only certain skills. For supervision in schools, it is oriented to the four National Education Standards (SNP). The four SNPs are: content standard, process standard, graduate competency standard (SKL) and assessment standard. The four SNPs are the teacher's field of work. Thus, the ability of teachers must be a serious concern and it is necessary to carry out coaching, development, monitoring and evaluation of teacher abilities by the principal as supervisor.

Efforts to improve the quality of education and teaching lie largely in increasing teacher activity in encouraging students to achieve goals. In order for the task of educating and teaching to be improved, teachers need guidance in the form of an understanding of the importance of the educational supervision function. Such efforts cannot be separated from the role of the principal who must be able to foster teachers to be sensitive and concerned about change and to be innovative and to always develop the quality of resources in teaching and educating.

However, the reality in the field shows that the tendency of teacher performance at SMPN 4 Banyuasin III is currently not optimal. Some of the factors that influence it are the teachers' low IT skills, insufficient infrastructure and less conducive conditions for the teacher's work environment. Thus the principal as the education leader in the school is required to be able to control and improve teacher performance in carrying out management professionally.

The teaching and learning process at SMPN 4 Banyuasin III is going well, but there are also things that must be evaluated such as teacher performance that has not been optimal in the teaching and learning process. As the results of observations (pre-research) that the author did with the principal and some teachers, there is a perception that teachers are less disciplined in carrying out their duties such as not preparing a Learning Implementation Plan, low quality of IT from teachers, and also lack of discipline in teaching time when the head schools are not in school or do not control the work of teachers, especially in the implementation of the teaching and learning process.

\section{Method}

The researcher chose a qualitative method in this study because the researcher wanted to describe the situation regarding the implementation of clinical supervision to improve teacher competence in developing learning methods at SMPN 4 Banyuasin III. The form of this research is case study research. This research was conducted at SMPN 4 Banyuasin III. In this study, there are several data collection techniques, namely 
observation, interviews, documentation. Meanwhile, the data collection tools used were observation sheets, interview sheets and documents.

\section{Results and Discussions}

The purpose The author carried out the stages of data collection from mid-July to August, assisted by existing teachers at the school. The description of the results of writing observations in class can be described in the stages carried out in the implementation of clinical supervision which can improve teacher competence in teaching, namely

\section{Initial Meeting Stage}

The initial stage of preparation begins by identifying learning problems which include teaching materials, learning difficulties of students and selecting appropriate learning methods to use in teaching and learning activities. The selected teaching materials must of course be adjusted to the current curriculum at SMPN 4 Banyuasin III. What is done at this stage includes the identification of learning problems, as well as the alternative solutions chosen. According to the teacher, the material that must be taught in the ongoing semester is Good Morning. How are you ?. This material is considered important because students can greet and show concern when meeting other people. This action is very important to be mastered by students to be able to maintain and even improve interpersonal relationships with teachers, friends, family, relatives, neighbors, and others. This material also teaches the ability of students to be able to say greetings in the form of saying goodbye, thanking, and apologizing.

The learning steps to be carried out in class VII are designed in Rp. In addition to preparing teaching materials and learning methods that will be used in teaching and learning activities, the teacher also prepares supervisors, who become supervisors in clinical supervision activities are the vice principal of the school / curriculum field. Selection of supervisors based on teacher expectations who can provide assistance for teacher difficulties in carrying out their teaching duties. The selection of a deputy principal / curriculum field supervisor as a supervisor has met the criteria desired by the teacher who will be supervised because he has attention to all activities in school, both learning and school management, extensive knowledge of educational, administrative and organizational issues, and is sympathetic and have high attention and concern for students and teachers in learning. The presence of the vice principal / curriculum field in these activities is very important because constructive information, suggestions and criticism from classroom learning activities can be valuable input for improving teacher performance in particular and improving school quality in general. The existence of a supervisor in this clinical supervision activity is more or less beneficial for the teacher concerned, because after the teaching observation process is completed and continues at the meeting stage, the supervisor together with the teacher concerned can identify things that need to be improved based on the teacher's experience and the results of the observations. supervisor.

At the initial meeting stage in the implementation of clinical supervision, it is known that every teacher is required to be able to make learning plans according to the abilities of students and to be able to identify sources of difficulties for students. This means that the teacher can indirectly improve the ability to manage learning by understanding the characteristics of students. According to the author, at this stage, it has touched on one of the aspects of competence that teachers must have, namely pedagogical competence, because the teacher has tried to manage learning by making learning plans and in this stage the teacher tries to change the views of students towards learning material that is considered difficult.

\section{Observation Stage Teaching}

This stage is carried out after all the learning devices are ready for use. Learning observation activities were carried out on August 3, 2020 at SMPN 4 Banyuasin III starting from 07:30 to 08:40 WIB. The learning was carried out by Tumina, S.Pd. in class 7.1 by taking Good morning material. How are you. The number of students in the class consists of 27 students and the learning process is carried out individually which will later be made into small groups with a seating layout forming the letter $U$ and learning methods and models that have been predetermined by the teacher concerned.

Before carrying out the teaching and learning process it is necessary to hold a brief meeting led by a supervisor. At this meeting, after the supervisor explains in general about the clinical supervision activities that will be carried out, then before the teacher starts learning, the teacher is given the opportunity to briefly state the plan. This information is very important for supervisors, especially for designing a plan of observations to be carried out in class. After the teacher delivers the explanation, then the supervisor enters class 7.1 to observe 
the course of learning. Supervisors are welcome to choose a strategic place so that they can observe the course of learning optimally. Then the teacher conducts the learning as planned.

The beginning of learning begins with curbing the classroom atmosphere and checking the attendance of students, then proceeding with perceptions that are still related to the material to be taught. In this learning the teacher uses the Contextual Teaching Learning (CTL) approach, contextual is a holistic educational process and aims to help students understand the meaning of the subject matter they are learning by linking the material with the context of their daily lives (personal, social and cultural contexts). ) so that students have knowledge that can be flexibly applied from one context to another. Meanwhile, the learning model uses Peer Tutor, which is learning that involves students as tutors to help teachers in the learning process to assist students in learning. Furthermore, the teacher explains the material with demonstrations or examples and gives open questions to stimulate students' thinking. After the teacher has finished explaining, students are formed into several small groups with heterogeneous levels of ability. Grouping of students is done by students taking the paper in the container provided. Then the students join their respective groups according to the serial number of the papers that are in them that they take, while peer tutors have been selected by the teacher based on a higher level of understanding ability compared to other students. Each group is given the task to understand and explain return the meaning of the greeting in its own language. The teacher calls representatives from each group to explain the meaning of a greeting. The teacher appreciates the representatives who have presented the results of the discussion and provided justifications.

Clinical supervision activities are attended by the deputy principal / curriculum officer as supervisor. The supervisor position is behind, the supervisor makes classroom observations based on the clinical supervision instrument sheet. Observation is mainly aimed at the interactions that occur between students and students in groups, interaction of students between groups in class discussions, interactions between teachers and students during the learning process, activities of students in learning, when students start learning, when do students began to look bored learning and when the students finished learning. Supervisors are not allowed to intervene in activities carried out by students, or those carried out by teachers. In this way, students are not bothered by the presence of a supervisor.

\section{Feedback Meeting Stage}

After completing the learning process, the next stage is the post observation stage. At the beginning of the post-observation stage, the teacher is given the opportunity to convey impressions about the learning activities that have been carried out. In the case of this clinical supervision activity, the teacher says that he does not feel nervous when doing learning even though there is a supervisor who observes when he teaches because the teacher is used to communicating with a superior who in this case becomes a supervisor. After the teacher conveys his impressions, the supervisor then submits suggestions and criticism that can be used as evaluation material for the supervised teacher so that performance and professionalism can increase.

Some things that still need to be improved are in terms of the use of media that have not varied, for example teachers can find and use interesting media so that the interest and motivation of students in participating in learning can increase, because of the limited media in these schools, it is necessary to use more varied media, as well as SK and KD please write on the blackboard. Then what must be improved is to provide questions that demand students' thought processes as well as follow-up questions that will encourage students to further explore the first answer.

\section{Conclusions}

To find out the benefits for teachers who have been under clinical supervision. Based on the results interviews and observations that have been carried out, namely a) Teachers can make improvements in the process of teaching and learning activities. b) With the implementation of clinical supervision can improve performance.c) Teachers can improve the overall quality of the school d)Provide motivation for teachers and students in teaching and learning activities. e)Teachers can find the right media to be applied in activities teaching and learning in order to increase students' understanding of a teaching material. f) Teachers become more creative and innovative in enhancing the learning atmosphere at classroom.

Suggestions that can be given in this research are that teachers should give a positive response to clinical supervision activities because they are able to bring changes for the better in terms of increasing the ability of teachers in the implementation of learning. 


\section{References}

Rohmat. Pilar Peningkatan Mutu Pendidikan. Yogyakarta: Cipta Media, 2012: 97.

Charisatuniswah, dkk.2012, Buku Kerja Pengawas Madrasah. Yogyakarta: Mapenda Kanwil Kemenang DIY, hal 15.

Ngalim Purwanto,2008Administrasi dan Supervisi Pendidikan. Bandung: PT. Remaja Rosda Karya,hal. 90. 